\title{
Stenography and Literature: What did Western European and Russian Writers Master the Art of Shorthand Writing For?*
}

\author{
IRINA ANDRIANOVA \\ Web-лаборатория Института филологии, Петрозаводский государственный университет, \\ пр. Ленина, д. 33, RU-185910 Петрозаводск \\ E-mail: yarysheva@yandex.ru
}

(Received: 3 March 2019; accepted: 2 June 2019)

The word stenography is of Greek origin ( $\sigma \tau \varepsilon v o ́ \varsigma$ 'narrow, compact' and $\gamma \rho \alpha ́ \varphi \omega$ 'to write'). This is the name of fast handwriting made by means of special signs and acronyms, permitting a person to listen to oral speech and record it simultaneously, and also to improve writing techniques.

Stenography is often taken for steganography, created when the first personal computers appeared (from Greek $\sigma \tau \varepsilon \gamma \alpha v o$ s 'covered, concealed, or protected' and $\gamma \rho \alpha ́(\varphi \omega$ 'to write'), a way of secret conveyance of information by means of keeping the fact of communication secret. At the moment, the latter one is widely in use and studied all over the world (linguistic, digital, network steganography, etc.) whereas, in contrast, stenography in the age of technological progress is essential for only few number of people and became a "dying art" (Summers 2011). Two centuries ago, being in fact a "photo" of true speech, stenography caused a revolution in the world but its history did not last forever...

Having appeared in Ancient Egypt, stenography is already more than 2,000 years of age. However, the first public use of stenography in history occurred in 63 B.C. in Ancient Rome. Then, the Senate in Sessions used "Tironian notes" invented by Tiro, a personal assistant of the orator Cicero. It was back in the 17th century that the symbolic, word or syllabic stenographic writing changed into a sound, alphabetical writing. Initially, stenography became widespread in England, France, Italy, Germany, and Austria-Hungary at the end of the 18th and the first third of the 19th century. ${ }^{1}$ In Russia, stenography found practical use only in the 1860 s when the judicial reform was implemented. Bar and jury associations as well as public hearing were established, and therefore, "specialists in stenography were in demand for keeping records of hearings [...] in courts of justice" (Юрковский 1969: 56). ${ }^{2}$

* The paper was funded by RFBR, project number 17-34-01075 “Anna Dostoevskaya's Stenographic Records: new materials and findings".

${ }^{1}$ About the history of stenography in European countries see ANDERSON 1882, BUTLER 1951.

${ }^{2}$ About the history of stenography in Russia see ЕРшов 1880, LOVELL 2015. 
All over the world, stenography was primarily used at meetings, sessions of state and public organizations, legislative, judicial, and other institutions. The invention of stenography was "comparable to the invention of printing, which gave an opportunity for the rapid spread of education by accelerating the exchange of ideas" (Длусский 1874: 25). For European and Russian public of that time, stenography was not just a manner of rapid writing but art and science as well. In the 19th century, it was believed that "in more or less distant future, common writing would be replaced by shorthand" (ЕРшов 1880: 4). "For the first time ever, human beings had a technology that allowed the written word to keep pace with speech and accurately record it" (Lovell 2015: 291). It significantly saved time and rendered invaluable support to people in various activities.

Many of those mastered shorthand or engaged professional stenographers to work. For example, the popular English memoirist Samuel Pepys (1633-1703), the physicist and mathematician Isaac Newton (1642-1727), the prominent politician, diplomat, and philosopher of the Age of Enlightment Thomas Jefferson (1743-1826), the German zoologist Alfred Brehm (1829-1884), the Russian chemist Dmitri I. Mendeleev (1834-1907), the father of Russian aviation Nikolai Ye. Zhukovsky (1847-1921), the geologist and paleontologist Vladimir O. Kovalevsky (1842-1883), the physiologist Ivan P. Pavlov (1849-1936), the agrochemist Dmitri N. Pryanishnikov (1865-1948), theatre directors Konstantin S. Stanislavsky (18631938) and Nikolai M. Gorchakov (1898-1958), and others.

Authors faced a seemingly impracticable task "to write down everything you think of". They were manual labourers as far as their thoughts "were hanging" at the tip of the pen. The perfection of writing process had an effect on such characteristics of their work as the minimization of physical efforts, time, and paper. M. I. Ivanin (1801-1874), an inventor of the first shorthand system in Russian, rightly pointed out: "There is no such thing as a poet or a writer who at the moments of inspiration would not wish to write down on a paper his impressions and ideas but common writing due to its slowness stifles the imagination, the inspiration ceases, and he transfers to the paper just a faint outline of the thoughts inspiring him; $[\ldots]$ whilst shorthand can follow every idea, passion, feeling, and expression that is catching on every word and expression quickly" (ИвАнин 1858: 20).

The purpose of this research is to reveal the role of stenography in the creative process of European and Russian writers and to draw social attention to the problem of the revival of interest in shorthand and the maintenance of this art.

Some researchers have uttered a curious opinion that a skilful approach of using shorthand was applied back in the times of the English poet and playwright William Shakespeare (1564-1616). ${ }^{3}$ To their mind, his plays were written down in secret by stenographers who used to attend the performances in the Globe Theatre. Those people were sent by rivals in order to get the text of the talented playwright's writings and make them performed on stages of other theatres without the author's permission. Later, the scholars detected a large number of mistakes in the publica-

\footnotetext{
${ }^{3}$ This viewpoint is given in SchmidT 1886, AdAms 1933, DAVIDSON 2009.
} 
tions of Shakespeare's plays that might be the result of imperfection of shorthand at that time. If this hypothesis is true, it turns out that readers and spectators in the 21 st century can enjoy many works of the great Shakespeare thanks to those stenographers-"thieves" of the 16th and early 17 th centuries. Nevertheless, "scholars today seem to overwhelmingly favour other explanations for textual inconsistencies in some of Shakespeare's early printed works" (FLAVIN).

We know four European writers mastering shorthand who lived and worked in different periods: Daniel Defoe (1660-1731), Charles Dickens (1812-1870), George Bernard Shaw (1856-1950), and Astrid Lindgren (1907-2002).

Daniel Defoe, the author of Robinson Crusoe studied stenography at a dissenting academy. "He grew up during the period of greatest repression of nonconformists, learned to read on the Bible, as a child piously copied out large sections of it in shorthand when a rumor went around that the High Churchmen were going to confiscate the dissenters' scriptures" (Dos PAssos 1954: 46). Shorthand skills helped Defoe in his further professional activities as a spy, ${ }^{4}$ a newsman, ${ }^{5}$ and a writer. ${ }^{6}$

The prominent novelist Charles Dickens learnt stenography at the age of 16 to 18 years based on the manual by Thomas Gurney. He practiced it while working as a freelance reporter at Doctors Commons courts from 1829 to 1831, and as a parliamentary reporter from 1831 to 1832 (for more, see Bowles 2017a). It is not a coincidence that one of the brightest Dickensian heroes, David Copperfield has autobiographical features and is a parliamentary stenographer. The writer's personal experience underlies David's story about how he mastered stenography: "I bought an approved scheme of the noble art and mystery of stenography [...] and plunged into a sea of perplexity that brought me, in a few weeks, to the confines of distraction. The changes that were rung upon dots, which in such a position meant such a thing, and in such another position something else, entirely different; the wonderful vagaries that were played by circles; the unaccountable consequences that resulted from marks like flies' legs..." (DiCKENS 1850: 385). In the end, David Copperfield (as well as his creator) successfully learnt the skills of shorthand: "I have tamed that savage stenographic mystery" (DickENs 1850: 443).

According to Hugo Bowles, "shorthand had become an integral part of his writing practice and although very little of his shorthand survives, he is known to have used it to draft articles, reports, letters, memos, and private notes throughout his writing career" (Bowles 2017a). In 1856, in his letter to Wilkie Collins, Dickens wrote: "I daresay I am at this present writing the best shorthand writer in the world" (HOGARTH-DiCKENS 1893: 399).

Stenography seems to have helped him in literary activity, too. Researchers believe that stenographic skills had an impact on Dickens's artistic style characterized by "orality", a tendency to use a "phonographic turn", and to prove what they

\footnotetext{
${ }^{4}$ About the activity of Defoe as a spy see, for instance, FURBANK-OwENS 2016.

${ }^{5}$ From 1704 to 1713, he alone published the newspaper A Review of the Affairs of France. The Review covered Defoe's many interests, both literary and historical, and it was published twice and later three times a week.

${ }^{6}$ Defoe is the author of nine novels, more than ten stories and essays as well as two poems.
} 
referred to as a "verbal explosion" of Mr. Pickwick (The Pickwick Papers) (see Gitelman 1999, Marcus 1972, Kreikamp 2005, Bowles 2017b, Bowles 2017c).

George Bernard Shaw, another writer-stenographer was a passionate critic of the English language, in which the gap between sounding (phonetics) and spelling (orthography) is particularly notable. Over many years, Shaw tried to make his contemporaries admit the necessity of a language reform. In his creative writings, he used a notation elaborated by an Englishman named Isaac Pitman, the so-called "Pitman shorthand", which he considered unsatisfactory. He applied this stenographic system when writing his diary from 1885 to 1897 and rough copies of his literary works. At the end of his life, Shaw bequeathed the major part of his fortune for working out a new graphic system of the English language. Just after his death based on a competitive examination procedure, an alphabet known as "Shaw Alphabet" or "Shavian" was invented, where the phonemes corresponded their graphic characters. However, native speakers did not accept the alphabet, and neither did specialists. ${ }^{7}$

For Astrid Lindgren, a Swedish writer in the 20th century, stenography was an indispensable part of creative process, her "working routine" (ANDERSEN 2018: 120). As a professional secretary and stenographer, Lindgren started using shorthand at the very beginning of her literary activity - since April 1944, when she was working upon her stories about a girl named Pippi. Jens Andersen, the biographer of the writer pointed out: "it was possible to capture thoughts and ideas in flight, writing down chains of sentences at lightning speed. [...] The method soon proved eminently practical for a bedridden amateur author, and so conductive to scribbling down everything she had in her head that Astrid Lindgren continued to write her rough drafts in shorthand for the rest of her career" (ANDERSEN 2018: 120).

Russian writers in the 19th and early 20th centuries also called upon the services of stenographers when working on their writings. A stenographer Ivan Markuze recalls that in the Russian press of the 1860 s, there were discussions on stenography as an interesting art. It was "a sort of 'the topic of the day', an urgent subject" (МАРКузЕ 1900: 982). Taking responsibility for the imposition of shorthand, the government set up free preparatory courses for stenographers.

Among the first writers who dared hold this creative experiment - to collaborate with stenographers - were those of different talent and recognition: Vsevolod Krestovsky (the end of The Slums of Petersburg, 1864-1866), Fyodor Dostoevsky (beginning with the novel The Gambler, 1866), Dmitry Girs (The Old and New Russia, 1868), Grigori De-Vollan. They knew each other and worked with stenographers during more or less the same period, i.e. the 1860s.

From May to November 1866, the Russian poet and prose writer V. Krestovsky dictated the final part of his novel The Slums of Petersburg to a stenographer named Ivan Markuze. Though V. Krestovsky was in a hurry to hand in the novel for publishing in the journal Otechestvennye zapiski, he was not pressed for time.

\footnotetext{
${ }^{7}$ For more information on the question see, for instance, MACCARTHY 1969.
} 
According to Ivan Markuze's recollections, the author of The Slums of Petersburg believed that the work within the framework of a shorthand system would allow him "to start dictating the novel when he felt like doing that, $[\ldots]$ and be back at work when he felt inspired again, voluntarily, just at the whim of imagination" (MАРКузЕ 1900: 981). The completion of Krestovsky's novel resulted in a delay. He fully completed it only at the beginning of November 1866.

Before starting his collaboration with a stenographer, Fyodor Dostoevsky used to write his works extremely pressed for time from month to month. It was a titanic job, a nonstop creative work. In 1865, under the risk of being imprisoned because of his debts, he concluded an enslaving contract with the publisher-speculator Fyodor Stellovsky, thus conceding to him the right to publish the complete works. Under the contract, Dostoevsky had to provide Stellovsky with a new novel for the third volume of the complete works. In case of failure to comply with this requirement until 1 November, the writer would have had to entrust his rights to literary works to the publisher for a nine-year term. Trapped into such a disadvantaged situation, Dostoevsky made up his mind to apply stenography in his literary activity.

Unlike Krestovsky, Dostoevsky would not have agreed to deal with a male stenographer since "the man was likely to begin drinking heavily" (ДостовВСКАЯ 2015: 109). The story of the appearance of a female stenographer in Dostoevsky's apartment, who became his wife later, was described in the memoirs of the eyewitnesses of the event. It is widely known at present and is seen by researchers as crucial for the private life and creative work of the writer. On the request of Alexander Milyukov, his colleague addressed to his friend Pavel Olkhin, professor of stenography, who recommended him to employ the twenty-year-old Anna Snitkina, who had finished a six-month study (from April through October 1866) at shorthand courses at the Sixth Saint Petersburg High School.

At 8 p.m. on 4 October 1866, "the methods of Dostoevsky's creative work considerably changed" (сf. Чулков 1939: 129): he began to dictate the novel The Gambler to the stenographer Snitkina, his future wife. The author of The Gambler and his assistant elaborated an empirically based model of creative activity wherein shorthand played a key role. Afterwards, while writing other books, this model of creative activity hardly ever changed.

At nights, he used to write, draw up a plan, and draft successive pages of the novel. In the afternoon, he dictated the results to Anna Grigorievna, improvizing during the dictation. In doing so, she "did not use to interrupt Dostoevsky even if she did not manage to write down his idea but used to leave brackets to be filled by the author himself after decoding and rewriting the text" (Кийко-ПОшЕмАнскАЯ 1978: 5). ${ }^{8}$ In the evening, the stenographer deciphered shorthand notes, and the following morning, the writer used to make corrections to her pages. The last step of this creative process was composing a manuscript. Anna made a fair copy of the

\footnotetext{
${ }^{8}$ The observation was made by an experienced stenographer of Soviet times Tsetsiliya Mironovna (Moiseevna) Poshemanskaya, who from the 1950s to the 1970s decoded a shorthand diary of Dostoevsky's wife (1867) and other archival materials in the writer's literary fund.
} 
text in accurate calligraphy, almost copperplate handwriting. Later, she recollected: "The more time went by, the more Fyodor Mikhailovich got involved into the work. He stopped dictating, orally inventing on the spot but worked at night dictating then based on his manuscript. Sometimes, he managed to write much so that I had to stay far after midnight rewriting the dictated pages. On the other hand, what a triumphant look I had the next day announcing the number of the pages added to those already written! I was so pleased to see a happy smile of Fyodor Mikhailovich in response to my assurances that the work was proceeding and that there was no doubt that it would be completed on time" (ДостоввскАЯ 2015: 120-121).

The work of the writer and the stenographer upon the novel The Gambler was finished by the date stipulated in the contract. On 30 October 1866, Dostoevsky dictated the closing lines to Anna Grigorievna, and on 1 November, the manuscript was handed over upon receipt to the officer on duty of the police unit for its further delivery to Stellovsky. The writer and his young employee made a feat as far as yet no one in the world literature had ever created a complete novel in less than 30 days. This record remains unbroken up to now. ${ }^{9}$ That success belonged not only to Dostoevsky and Anna Snitkina but also to her teacher, P. M. Olkhin. Over 20 years, he was engaged in "the application of various shorthand systems for the Russian language" (Ольхин 1866: 2) and finally managed to elaborate his own system based on principles of the German shorthand of Gabelsberger, the system that underlay the work of Dostoevsky and his assistant.

Dostoevsky had a plan he declared to his wife on 15 (27) July 1876: "having moved to Saint Petersburg, you will stop taking down my writings in shorthand and rewriting them. That is what I decided" (Достоввский 1985b: 99). However, during all his life, the writer's plan remained a dream impossible to come true.

Stenography became a part of Dostoevsky's creative process, although it remained a mysterious art for him: "I would give much to know what you are writing with your unreadable characters, Anechka" (Достоевская 2015: 206). In the letter to his niece Sofia Aleksandrovna Ivanova dated on 29 March (10 April) 1868, he called shorthand a "high art", inviting the girl to master it in a professional manner: "would you like to study stenography? Pay attention, Sonechka: stenography is a high art that does not insult the profession but does bring honour and great means of subsistence to those who master the art" (Достоввский 1985a: 293).

Dostoevsky's daughter, Ljubov Fyodorovna made a fair conclusion: "Dostoevsky would not have written so many novels if his wife had not come up with the bright idea to study stenography" (Достоввская 1922: 82). During the time of their marriage (from 1866 to 1881), the writer's artistic talent reached its peak and the major part of his literary heritage was established, and the great novel The Brothers Karamazov dedicated to Anna Dostoevskaya was published. Ch. Dickens

${ }^{9}$ A 26-day term is defined as the term of writing of the novel The Gambler in the memoirs of A. G. Dostoevskaya. In his letter to A. P. Suslova dated 23 April (5 May) 1867, Dostoevsky pointed out a shorter term of the work upon the novel for Stellovsky: "28 November: the novel The Gambler (already published) was finished at midnight” (Достоввский 1985a: 182). 
described himself as "the best writer-stenographer" of the 19th century whereas Dostoevsky became the great admirer of the "high art" of stenography.

After reading one of the books by the French stenographer A. Grosselin in 1846, the Russian critic and columnist N. G. Chernyshevsky worked out his own original system of semi-stenographic writing of various grammatical forms and structures by means of abbreviations and symbols, which he used to keep his personal diary from 1852 to 1853 (for more, see АлЕКСеЕв 1936, ПротАСов 1928, Рейсер 1982: 48). During his stay in Astrakhan and Saratov from 1883 to 1889 , he employed a professional stenographer. As I. Paperno pointed out, "as a result, he could work much faster; thus, four days before his death the gravely ill Chernyshevsky managed to dictate eighteen pages of the translated Outlines of Universal History by Georg Weber. His final words said when he was in the near-death delirium were also written down in shorthand by his secretary" (ПаПЕРно 1996: 45). According to the researcher, Chernyshevsky was impressed by the opportunities stenography presented, and often mentioned it in his writings; he preferred stenography to other ways of writing since the immediate experience became real, extensive, and constant in a word stream of instantaneously fixed feelings (see ПАПЕРНО 1996: 46).

From 1907 to 1909, Leo Tolstoy used the help of the stenographer-copyist Nikolai Gusev: in this case, stenography was applied not for writing but for dictating responses to numerous letters addressed to the writer. He left this method aside while writing his literary works and once confessed to the stenographer: "...I am a little bit ashamed... While writing a literary work these rough copies serve you only to remind the feelings that accompany the writing process. I feel embarrassed to hand them over to another person. I do them for myself. While writing an article, you try to render it complete [some articles by Tolstoy in the later years of his life were written down in shorthand by N. N. Gusev - I. A.]" (Гусев 1909).

By the way, a similar feeling was inherent to Nikolai Leskov, who refused to "dictate even letters" (МАРКузЕ 1900: 989), neither did he imagine how another person could take part in his creative process, though technically. Alone, with a quill in hands, in absolute silence of the night, and with a sheet of paper in front of him - only under these conditions was the author of Lady Macbeth and The Cathedral Clergy able to write (МАРКузЕ 1900: 988).

Alexander Kuprin used to apply stenography in his creative process. As it results from his correspondence in 1907, he dictated the lost story Life to a stenographer, and then in 1914, he worked upon the final pages of the story The Pit (for more, see Кулешов 1983). Moreover, considering that the author agonized long and hard over the second part of The Pit (he worked on it for six years), it was the involvement of the stenographer in the literary process that finally allowed Kuprin to complete this literary work. "I am not a person of a strong will," admitted the writer in his interview in April 1914, "sometimes I find it difficult to discipline myself to work. However, as soon as the stenographer has come, I have to go to work whether I want it or not. It is hard to begin but then you get engaged in the process and begin feeling rather satisfied with your work" (КупРин). 
The men of letters that used stenography while creating their works could assess from their own experience unique mobility of writing down in shorthand (they needed for work only paper and a pencil/quill/pen), the synchronism of fixing a train of thoughts and the velocity of making records that substantially saved time.

The writers who mastered the art of shorthand found themselves in favour in other spheres of professional activities (Defoe and Dickens), Stenography formed part of the creative process of the writers who used it, saved their time and physical efforts, let them avoid poverty and enslaving terms of the contracts with publishers (Dostoevsky, Krestovsky, Shaw, and Lindgren). Their literary works became famous in the entire world mostly thanks to stenography.

In the 21 st century, there are some technologies for real-time recording that have replaced stenography. The first two technologies are used only by experts and consist in applying a stenotype machine that represents a small electronic device plugged in the computer, thus, the text typed on the specialized chorded keyboard is automatically processed and decoded by means of special software. The second technology consists in using devices that transform speech into text (such as a Stenomask, which functions based on the automatic process of speech recognition). However, these highly specialized devices are not widely spread. Recorders with further decipherment of their digital audio recordings have received a broader use.

The art of shorthand nowadays is experiencing a crisis and is on the brink of extinction. As a result, on 29 September 2014, the members of the international community of stenographers Intersteno took the initiative to declare shorthand a UNESCO intangible cultural heritage needing protection, and announced the necessity of the establishment of the Web-Archive of the books on stenography. ${ }^{10}$ Actually, the world stenography needs maintenance. M. Mann and Stephen A. Schwarzman revealed the key reason for that, "even if you do not wish to write in shorthand yourself, you may need to decipher it in order to pursue archival research" (MANN-SCHWARZMAN). European and Russian archival collections contain numerous documents written in shorthand. Thus, the Manuscript Departments of the Institute of Russian Literature and of the Russian State Library as well as the Russian State Archive of Literature and Arts keep about 25 documents of the Dostoevsky literary fund with some stenographic notes on them. The New York Public Library contains verbatim transcripts from "the collection of George Bernard Shaw" (MANN-Schwarzman). The National Library of Sweden in Stockholm owns "the stenographic notebooks (660 notebooks)" belonging to A. Lindgren "with rough copies written over 50 years that are unreadable to anyone except a professional stenographer" (ANDERSEN 2018: 121). A part of these notes are not deciphered, and the deciphered part needs clarification. "As the number of people capable of reading shorthand decreases, these unique manuscripts practically become ciphers symbols for future research codebreakers to tackle" (MANN-SCHWARZMAN).

${ }^{10}$ The meetings of the Scientific Committee. International Federation for Information and Communication Processing (Intersteno) E-news 70. October 2015, p. 14. http://www.intersteno.org/ wp-content/uploads/2015/10/enews70.pdf. 


\section{References}

AdAms 1933 = AdAms Joseph Quincy: The Quarto of King Lear and Shorthand. Modern Philology 31 (1933): 135-163.

Andersen 2018 = Andersen J. Astrid Lindgren. The Woman Behind Pippi Longstocking. New Haven, 2018.

ANDERSON $1882=$ ANDERSON T. History of Shorthand. With a Review of Its Present Condition and Prospects in Europe and America. London, 1882.

Bowles 2017a = Bowles H. Dickens's Shorthand Deciphered by Identifying 'Sydney Smith' Source Text. Notes and Queries 64 (2017): 614-617.

Bowles $2017 \mathrm{~b}=$ Bowles H. Stenography and Orality in Dickens: Rethinking the Phonographic Myth. Dickens Studies Annual 48 (2017): 21-44.

Bowles 2017c = Bowles H. The Stenographic Creativity of Charles Dickens. Paper Presented at the 28th AIA Conference Worlds of Words: Complexity, Creativity and Conventionality in English Language, Literature and Culture. Pisa, 14-16 September 2017.

Butler 1951 = ButLer E. H. The Story of British Shorthand. London, 1951.

DAVIDSON $2009=$ DAVIDSON A. Shakespeare in Shorthand. The Textual Mystery of King Lear. Newark, 2009.

Dickens 1850 = Dickens Charles: David Copperfield . London, 1850 .

Dos Passos 1954 = Dos Passos John: Daniel Defoe. In: Ford Edwin H., EMERy Edwin (ed.): Highlights in the History of the American Press. Minneapolis, 1954. 46-52.

FLAVIN = FLAVIN Richard: Shakespeare and Shorthand. http://www.flavinscorner.com/ shakespeare.htm.

Furbank-Owens $2016=$ Furbank P. N., Owens W. R. A Political Biography of Daniel Defoe. Abingdon, 2016.

Gitelman 1999 = Gitelman L. Scripts, Grooves, and Writing Machines. Representing Technology in the Edison Era. Stanford, 1999.

Hogarth-Dickens 1893 = Hogarth Georgina, Dickens Mary (ed.): Letters of Charles Dickens (1833-1870). London, 1893.

KREIKAMP 2005 = KREIKAMP I. Voice and the Victorian Storyteller. Cambridge, 2005. 6988.

LOVELL $2015=$ LOVELL St. Stenography and the public sphere in modern Russia. Cahiers du monde russe 56 (2015): 291-325.

MacCARThy $1969=$ MacCarthy P. A. D. The Bernard Shaw Alphabet. In: HaAs W. (ed.) Alphabets for English. Manchester, 1969. 105-118.

Mann-Schwarzman = Mann M., Schwarzman S. A. Despotic Characters. Researching Shorthand at the New York Public Library. https://www.nypl.org/blog/2015/05/27/ researching-shorthand.

MARCuS 1972 = MARCuS S. Language into Structure. Pickwick Revisited. Daedalus 1972/1: $183-202$.

SCHMIDT 1886 = SchmidT Alexander: Shakespeare Lexicon. A Complete Dictionary of all the English Words, Phrases and Constructions in the Works of the Poet. London, 1886.

SuMMERs 2011 = SuMmers Chris: Is stenography a dying art? BBC News, 27 April 2011. http://www.bbc.com/news/magazine-13035979.

АЛЕКСЕЕВ 1936 = АЛЕКСЕев Н. А. «Шифр» Н. Чернышевского. Красный архив 1936/3: $221-225$.

ГуСев $1909=$ Гусев Н. Н. Два года С Л. Н. Толстым. Дневник 10 апреля -14 июня 1909 2. http://tolstoy-lit.ru/tolstoy/bio/gusev-dva-goda/10-aprelya-14-iyulya-1909.htm. 
Длусский 1874 = Длусский С. Что такое стенография? Значение ее в историческом, общественном и педагогическом отношениях. Санкт-Петербург, 1874.

ДоСТОЕВСКАЯ 1922 = ДоСТОЕВСКАЯ Л. Ф. Достоевский в изображении его дочери Л. Достоевской. Москва-Петроград, 1922.

ДоСТОЕВСКАЯ 2015 = ДоСТОЕВСКАЯ А. Г. Воспоминания. 1846-1917. Москва, 2015.

ДостоЕвСКИй $1985 \mathrm{a}=$ ДостоЕвСКИй Ф. М. Полное собрание сочинений в 30 томах. Т. 28. Кн. 2. Ленинград, 1985.

ДостоЕВский $1985 \mathrm{~b}=$ ДостоЕВСКий Ф. М. Полное собрание сочинений в 30 томах. Т. 29. Кн. 2. Ленинград, 1985.

ЕРшов 1880 = ЕРшов Н. А. Обзор русских стенографических систем. Санкт-Петербург, 1880.

ИВАНИН 1858 = ИвАНИН М. О стенографии или искусстве скорописи, в применении ее к русскому языку. Санкт-Петербург, 1858.

КИЙКО-ПОШЕМАНСКАЯ 1978 = КИЙКО Е. И., ПОШЕМАНСКАЯ Ц. М. НеИзвестНЫЙ источник текста романа «Братья Карамазовы». В кн.: Достоевский. Материаль и исследования. Т. 3. Ленинград, 1978.

КуЛЕШОВ 1983 = КуЛЕШОВ Ф. И. Творческий путь А. И. Куприна. 1883-1907. Минск, 1983.

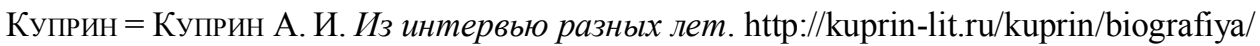
iz-intervyu-raznyh-let.htm.

МАРКУЗЕ 1900 = МАРКУЗЕ И. К. Воспоминания о В. В. Крестовском. Исторический вестник. Т. 79. Москва, 1900. 979-1003.

Ольхин 1866 = Ольхин П. Руководство к русской стенографии по началам Габельсбергера. Санкт-Петербург, 1866.

ПАПЕРНО 1996 = ПАПЕРНО И. Семиотика поведения. Николай Черныиевский - человек эпохи реализма. Москва, 1996.

ПрОТАСОВ 1928 = ПрОТАСОВ И. Ф. О рукописи Чернышевского. Вопросы стенографии и машинописи 1928/12: 3-5.

РЕЙСЕР 1982 = РЕЙСЕР С. А. Русская палеография нового времени. Неография. Москва, 1982.

Чулков 1939 = Чулков Г. И. Как работал Достоевский. Москва, 1939.

Юрковский 1969 = Юрковский А. М. Стенография сквозь века. Очерки по истории стенографии. Москва, 1969.

\section{IRINA ANDRIANOVA}

WEB-laboratory, Institute of Philology, Petrozavodsk State University (Petrozavodsk)

\section{Stenography and Literature: What did Western European and Russian Writers Master the Art of Shorthand Writing For?}

What brings together Daniel Defoe, Charles Dickens, Vsevolod Krestovsky, Nikolai Chernyshevsky, Fyodor Dostoevsky, Alexander Kuprin, George Bernard Shaw, and Astrid Lindgren, i.e. writers from different countries and belonging to different epochs? In their creative work, they all used stenography, or rapid writing, permitting a person to listen to true speech and record it simultaneously.

This paper discloses the role of stenography in literary activities of European and Russian writers in the 19 th and early 20 th centuries. Some researchers believe that the 
first ties between shorthand and literature appeared in the days of Shakespeare when the playwright's competitors used shorthand to put down the texts of his plays. Others have convincingly refuted this viewpoint, proving that such records never existed. The most famous English novelist in the 17th and 18th centuries Daniel Defoe can be considered one of the first writers who used shorthand in his literary work. The writers mastering the art of shorthand writing such as Defoe, Dickens, and Lindgren were popular in various professional spheres (among others, the secret service, journalism, and secretarial service) where they successfully applied their skills in shorthand writing.

Stenography was an integral part of a creative process of the authors who resorted to it (Dostoevsky, Krestovsky, Shaw, and Lindgren). It economized their time and efforts, saved them from poverty and from the terms of enslavement stipulated in the contracts between writers and publishers. It is mainly thanks to stenography that their works became renowned all over the world. If Charles Dickens called himself "the best writer-stenographer" of the 19th century, F. M. Dostoevsky became a great admirer of the "high art" of shorthand. He was the second writer in Russia (following V. Krestovsky), who applied shorthand writing in his literary work but the only one in the world literature for whom stenography became something more than just shorthand. This art modified and enriched the model of his creative process not for a while but for life, and it had an influence on the poetics of his novels and the story A Gentle Creature, and led to changes in the writer's private life. In the course of the years of the marriage of Dostoevsky and his stenographer Anna Snitkina, the author's artistic talent came to the peak. The largest and most important part of his literary writings was created in that period.

As a matter of fact, having become the "photograph" of live speech two centuries ago, shorthand made a revolution in the world, and became art and science for people. However, its history did not turn to be everlasting. In the 21 st century, the art of shorthand writing is on the edge of disappearing and in deep crisis. The author of the paper touches upon the problem of revival of social interest in stenography and its maintenance as an art. Archival collections in Europe and Russia contain numerous documents written in shorthand by means of various shorthand systems. If humanity does not study shorthand and loses the ability to read verbatim records, the content of these documents will be hidden for us forever.

Keywords: stenography, Russian literature, the art of shorthand writing, archives, the heritage of mankind, creative process, Dickens, Dostoevsky, Defoe, Lindgren, G. B. Shaw 